\title{
TABLE OF CONTENTS
}

\section{HUGOYE 4:1}

In Memoriam

Fr. Yousef Habbi (1938-2000)............................................................

Prof. Julius Assfalg (1919-2001) ...........................................................

Papers

L'origine du nom Bar 'Ebroyo:

Une vieille histoire d'homonymes .......................................................

Jean Fathi-Chelhod

Simeon of Qalca Rumaita, Patriarch Philoxenus

Nemrod and Bar cEbroyo

Hidemi Takahashi

Brief Articles

Syriac Papyrus Fragments Recently Discovered

in Deir al-Surian (Egypt)

Fr. Bigoul El-Souriany, Lucas Van Rompay

Recent Archaeological Excavations in Takrit

and the Discovery of Syriac Inscriptions....

Amir Harrak

A New Syriac Inscription in Deir al-Surian (Egypt)

Lucas Van Rompay, Andrea B. Schmidt

Publications and Book Reviews

Conference Reports

Forthcoming Conferences / Call for Papers 


\section{HUGOYE 4:2}

Introduction to Hugoye 4:2 (July 2001) ...........................................155

Susan A. Harvey

Papers

"Bold and Having No Shame:" Ambiguous Widows,

Controlling Clergy, and Early Syrian Communities.

Michael Penn

Women in Aphrahat: Some Observations

Adam Lehto

Theodora the "Believing Queen:"

A Study in Syriac Historiographical Tradition

Susan A. Harvey

Hindiyya Anne cajaymi and Her Spiritual Journey:

The Essential Lightness of Being

Avril M. Makhlouf

Brief Articles

Deir al-Surian (Egypt):

conservation work of Autumn 2000

Karel C. Innemée

eBethArké: The Syriac Digital Library. First Report .269

George A. Kiraz

Publications and Book Reviews .273

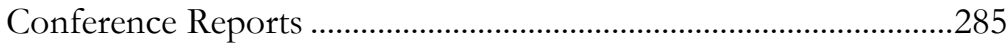

Forthcoming Conferences / Call for Papers ..................................291 